\title{
The Effects of Varieties Sources of Omega-3 Fatty Acids on Diabetes in Rats
}

\section{Sahar Soltan Abdel Magied Soltan}

Home Economics (Nutrition \& Food Science), Faculty of Specific Education, Fayoum University, Al Fayoum, Egypt.

Email: ssamsoltan@hotmail.com

Received August $5^{\text {th }}, 2012$; revised September $5^{\text {th }}, 2012$; accepted September $12^{\text {th }}, 2012$

\begin{abstract}
The aim of this study was to investigate the effects of varieties sources of omega- 3 on diabetic rats. Fifty six male albino rats were divided into 7 groups: first group was fed on normal basal diet (maintained at negative control group), group 2 diabetic group fed on $60 \%$ fructose, group 3 fed on $60 \%$ fructose $+8 \%$ fish oil, group 4 fed on $60 \%$ fructose + $8 \%$ flaxseed oil, group 5 fed on $60 \%$ fructose $+4 \%$ corn oil $+4 \%$ fish oil, group 6 fed on $60 \%$ fructose $+4 \%$ corn oil + $4 \%$ flaxseed oil and group 7 fed on $60 \%$ fructose $+4 \%$ fish oil $+4 \%$ flaxseed oil. Fatty acid composition of investigated oils showed that the corn oil contained high levels of omega-6 fatty acid (LA: 56.95\%), flaxseed oil contained high level of short chain omega-3 fatty acid (ALA: 56.31\%), meanwhile fish oil only has high concentration of long chain omega-3 fatty acid $39.20 \%$ (23.98\% of EPA and $15.22 \%$ of DHA). After 8 weeks feeding of fish oil, flaxseed oil, corn oil + fish oil, corn oil + flaxseed oil and fish oil + flaxseed oil showed reducing levels of glucose by $49.09 \%, 44.0 \%$, $43.4 \%, 43.6 \%$ and $44.9 \%$ respectively. Data revealed significant decrease $(P<0.05 \%)$ was observed of TC, TG, LDL and VLDL of all treatment. Urea and creatinine in diabetic rats was increased, in contrast the glutathione reduced was decrease compared to the control group. Fish oil showed the highest decrease in urea and creatinene and the highest increase in glutathione levels and insulin compared to other sources of omega-3. Omega-3 fatty acids have potential effect to protect pancreas from up normality changes which induced in diabetic disease. The data suggested that omega-3 fatty acid and fish oil especially may be effective in the prevention of diabetic disease.
\end{abstract}

Keywords: Diabetes Mellitus; Omega-3; Fish Oil; Flaxseed Oil; Corn Oil; Insulin; Antioxidant Enzyme

\section{Introduction}

Diabetes mellitus is considered as a common, growing, serious, costly and potentially preventable public health problem. In 2030, the number of people with diabetes is estimated to increase from 117 million in 2000 to 366 million [1]. The prevalence rate is $8.9 \%-12.3 \%$ in human population [2]. Diabetes is a disease of carbohydrate metabolism, but it is a general metabolic disorder of all three of the energy nutrients fat, carbohydrate and protein [3]. The most common problem encountered in diabetes mellitus is atherosclerotic cardiovascular disease [4], seen frequently associated with typical dyslipidaemia, including hypertriglycridaemia. Hypercholesterolemia low levels of high density lipoprotein cholesterol (HDL-c) and high level of low density lipoprotein cholesterol (LDL-c) [5].

On the other hand there is low prevalence of diabetes in Greenland [6] and Alaskan Eskimos [7] as well in people living in the Faeroe Islands [8], populations known for a very high intake of omega- 3 fatty acids. The prevalence of diabetes mellitus in Alaska has found that
15.7/1000 subject was lower than over United States vat of 24.7/1000 and 8.8/1000 among Alaskan Eskimos [9]. The lower prevalence of diabetes in this population due to their higher intake of omega-3 rich fish and marine mammals [10]. Average daily consumption of omega-3 among about $3-4 \mathrm{~g} / \mathrm{d}$ compared to with $0.2 \mathrm{~g} / \mathrm{d}$ by the American population [11]. The prevalence of diabetes in Egypt in 2008 was $4.07 \%$. The global prevalence of diabetic in the year 2010 among adults has been estimated to be $6.4 \%$. It is estimated that by the year 2030, Egypt will have at least 8.6 million adults with diabetes [12].

There are three types of omega- 3 in foods. The short chain is alpha linolenic acid ALA: 18:3n-3 (Cis-9,12,5, octadecatrienoic acid), and long chain is eicosapentaenoic acid EPA: 20:5n-3 (Cis-5,8,11,14,17-eicosapentaenoic acid) and docosahexaenoic acid DHA: 22-6n-3 (Cis-4,7,10,13,16,19 docosahexaenoic acid).The major sources of ALA are vegetable oils (such as canola and soybean) with other sources being flaxseed oil. Flaxseed is alternative to plant source of omega-3 fatty acid. It is one of the richest plant sources of omega-3 fatty acid alpha-linolenic (ALA, C18:3n-3) [13]. The bioavailabil- 
ity of ALA is greater in oil than in milled seed flaxseed and has greater bioavailability in milled seed than in whole seed [14]. A total intake of ALA 1.5 - $3 \mathrm{~g} /$ day appears too beneficial. While fish and fish oil is major sources of EPA and DHA. British National Foundation recommends females and males have an intake of DHA/ EPA of 1.1 and $1.4 \mathrm{~g} /$ day, respectively [15]. An increased intake of omega-3 fatty acids might reduce the risk of developing diabetes has been tested in mice, where supplementation with fish oil inhibited hyperglycemia and pancreatic insulitis in streptoztocin-induced diabetes. Also omega-3 fatty acid can reduce insulin resistance in skeletal muscle [16]. ALA is considered to be nutritionally essential because of its specific function as precursor of the long-chain n-3 PUFA [17]. The higher consumption of ALA was associated with higher plasma insulin and improves glucose used and efficiency [18]. EPA and DHA act as hypolipidamics exert prophylactic effects on cardiovascular disease, protect against insulin resistance and obesity in rodent fed high diet and insulin response to glucose in healthy human [19,20]. Polyunsaturated fatty acid (EPA and DHA) play a central role in normal development and functioning of the brain and central system [21]. EPA and DHA also plus a major role in regulating inflammation via substances called prostaglandins. EPA and DHA produced anti-inflammatory prostaglandin.

The relationship of trace elements with coronary artery disease and diabetes may be best examined by comparing population that have larger in dietary consumption of minerals and more pronounced differences in the prevalence of diabetes and coronary artery disease. Zinc is required for normal immune function and taste a acuity and enhances the in vitro effectiveness of insulin [22].

The aim of the present study was to investigate the effects of fish oil and flaxseed oil and mixed from fish oil and flaxseed oil as the different sources of omega- 3 fatty acids on serum glucose, lipid profile (including total cholesterol, HDL-c, LDL-c, Triacylglycerids), kidney function (serum urea and creatinine), antioxidant enzyme (glutathione reduced), insulin and serum zinc in diabetes rats by high fructose diet.

\section{Materials and Methods}

\subsection{Materials}

Fish oil (omega-3 plus) was purchased from Sedico Pharmaceutical Company 6-October City-Egypt. Flaxseed oil was purchased from Tanta of oils and flaxseed Company. Corn oil was purchased from local marked. All of kits were purchased from Bio-diagnostic 29 Tahreer St., Dokki, Giza, Egypt.

Fatty acid analysis of oils was determined using the method of [23]. Fatty acid was converted to fatty acid methyl ester according to the method by [24]. Trace GC Mass Ultra thermo was used to separate fatty acids on 10 m capillary Colum $(0.1 \mathrm{~nm}$ ID $\times 0.2 \mu \mathrm{m})$. The carrier gas used was helium set at a flow rate of $0.5 \mathrm{ml} / \mathrm{min}$ and split less. Time $1 \mathrm{~min}$. The injection temperature was $250^{\circ} \mathrm{C}$ and the FID detector was $350^{\circ} \mathrm{C}$. Initial oven temperature was $40^{\circ} \mathrm{C}$ and rose to $230^{\circ} \mathrm{C}$ and holding for $20 \mathrm{~min}$. Identification of compounds was based on molecular weight of fatty acids.

\subsection{Experimental Design}

Fifty six male albino rats weighing between $100-120$ grams were obtained from animal house of Otphthalmic Institute Academic Research Giza, Egypt. The animal housed individually in stainless steal cages under controlled condition at constant temperature $\left(22^{\circ} \mathrm{C}\right)$ and lighting $12 \mathrm{~h}$. light-dark cycle) and given free access to food and water at all time. The rats were divided randomly into seven groups - eight rats in each group and fed the fallowing diets for 8 weeks:

Group 1: Rats were fed on standard diet mentioned as normal control (negative control group).

Standard diet was prepared according to [25]. It contained $14 \%$ casein, $2 \%$ cellulose, $5 \%$ salt mixture, $1 \%$ vitamin mixture, $0.25 \%$ choline, $0.3 \%$ Dl-methionine, $8 \%$ corn oil and remaining percentage was starch.

Group 2: Rats were fed on fructose rich diet $60 \%$ as a diabetic control group (positive control group). Fructose rich diet was prepared according to [26]. It contained 600 gram fructose for each $1 \mathrm{~kg}$ diet (it is similar to standard diet but containing $60 \%$ fructose).

Group 3: Rats were fed on fructose rich diet $+8 \%$ fish oil (omega-3 plus).

Group 4: Rats were fed on fructose rich diet $+8 \%$ flaxseed oil.

Group 5: Rats were fed on fructose rich diet $+4 \%$ corn oil $+4 \%$ fish oil.

Group 6: Rats were fed on fructose rich diet $+4 \%$ corn $+4 \%$ flaxseed oil.

Group 7: Rats were fed on fructose rich diet $+4 \%$ fish oil $+4 \%$ flaxseed oil

Corn oil was added to fish oil and flaxseed oil to reduce metallic or fishy flavor and bitter taste of oils.

Each rat was weight at the initial and the end of experimental and food intake also was recorded daily. At the end of experiment ( 8 weeks), rats were killed after an overnight fast and blood of each rat was collected in two tubes. The first tube was containing sodium fluoride to preserve glucose to determined of glucose. The blood in the second tube was centrifuged at $3000 \mathrm{rpm}$ for $20 \mathrm{~min}$ utes to obtain the serum, which is kept at $-20^{\circ} \mathrm{C}$ until analysis.

Serum glucose, serum total cholesterol, serum HDL-c, 
serum LDL-c and serum triacylglycerol were determined according to [27-31] respectively. Serum urea and serum cretinine were determined according to [32,33] respectively. Serum glutathione reduced (GSH) and serum zinc were determined by $[34,35]$.

\subsection{Histopatholagical Assessment}

At necropsy, the pancreas fixed in $10 \%$ buffered formalin until analysis. Tissue slices were routinely processed for paraffin embedding and sections were prepared and stained with hematoxylin and eosin. Histopathological assessment was performed by light microscope, X-400 on all tissues of the control group and treatment.

\subsection{Statistical Method}

Analysis of the data was of preventative variables in form mean \pm SD buy SPSS windows version 17.0 according to Snedecoer and Cochranl [36]. A NOVA (analysis of variance) used for comparison of $P$ value (probability).

\section{Results and Discussion}

Data in Table 1 show fatty acid composition of investigated oils sample. Results showed that corn oil contained high levels of omega- 6 fatty acid (56.95\%) and low level of short chain omega-3 $(0.94 \%)$. Corn oil does not contain any long chain PUFA (EPA and DHA). These results are in agreement with Petersen et al. [37]. Who reported that omega- 6 fatty acid (linoleic acid) was the major fatty acid in corn oil $(55.9 \%)$.

Flaxseed oil contained low level of SFA (7.38\%) and omega-6 (10.77\%) while it contained high level of short chain omega-3 fatty acid (ALA: 56.31\%). Flaxseed oil does not contain long chain n-3 fatty acid (EPA and DHA). These results are in line with those [38-41].
Fish oil only has high concentration of long chain omega-3 fatty acid $39.20 \%$ (23.98\% of EPA and $15.22 \%$ of DHA). These results are agreement with $[42,43]$ who mentioned that the long chain polyunsaturated fatty acid was found mainly in fish and fish oil. Fish and fish oil are the only major dietary source for human of omega-3 long chain fatty acid [44].

Data in Table 1 also shows fatty acids analysis of the mixed of corn and fish oils; corn and flaxseed oils; fish and flaxseed oils; mixed of corn and flaxseed oils contained lower level of ALA (28.625\%) than in flaxseed oil (56.31\%); and higher level of omega-6 (33.86\%) than flaxseed oil (10.77\%).

Mixed of corn and fish oils contained lower level of short chain omega-3 ALA $(0.47 \%)$ than corn oil $(0.94 \%)$, and moderately level $(20.07 \%)$ of long chain omega-3. Mixed of fish and flaxseed oils contained moderately level of ALA (28.155\%) and enrichment in long chain omega-3 (EPA and DHA (19.60\%). These results are accordance with data reported by Campioli et al., [44] who reported that use mixed oil (flaxseed and fish oil) enrichment in EPA and DHA is preferable to the one containing of ALA.

Data in Table 2 demonstrated that there are no significant different $(P \leq 0.05 \%)$ between seven studies groups in initial body weight (mean ranged between $113.33 \pm 2.58^{\mathrm{a}}$ to $115 \pm 5.48^{\mathrm{a}}$ gram).

Data presented in Table 2 showed that there are no significant different $(P \leq 0.05 \%)$ in food intake in diabetic group, diabetic rats $+8 \%$ flaxseed oil and diabetic rats $+4 \%$ corn $+4 \%$ flaxseed oils compared to control group. Meanwhile the lowest value of food intake was observed in group 3 (fed on $8 \%$ fish oil), group 5 (fed on $4 \%$ corn $+4 \%$ fish oils) and group 7 (fed on $4 \%$ fish + $4 \%$ flaxseed oils). These may be due to decrease appetite of food because fishy flavor or metallic flavor of fish oil.

Table 1. Relative percentage of fatty acid composition in investigated oils.

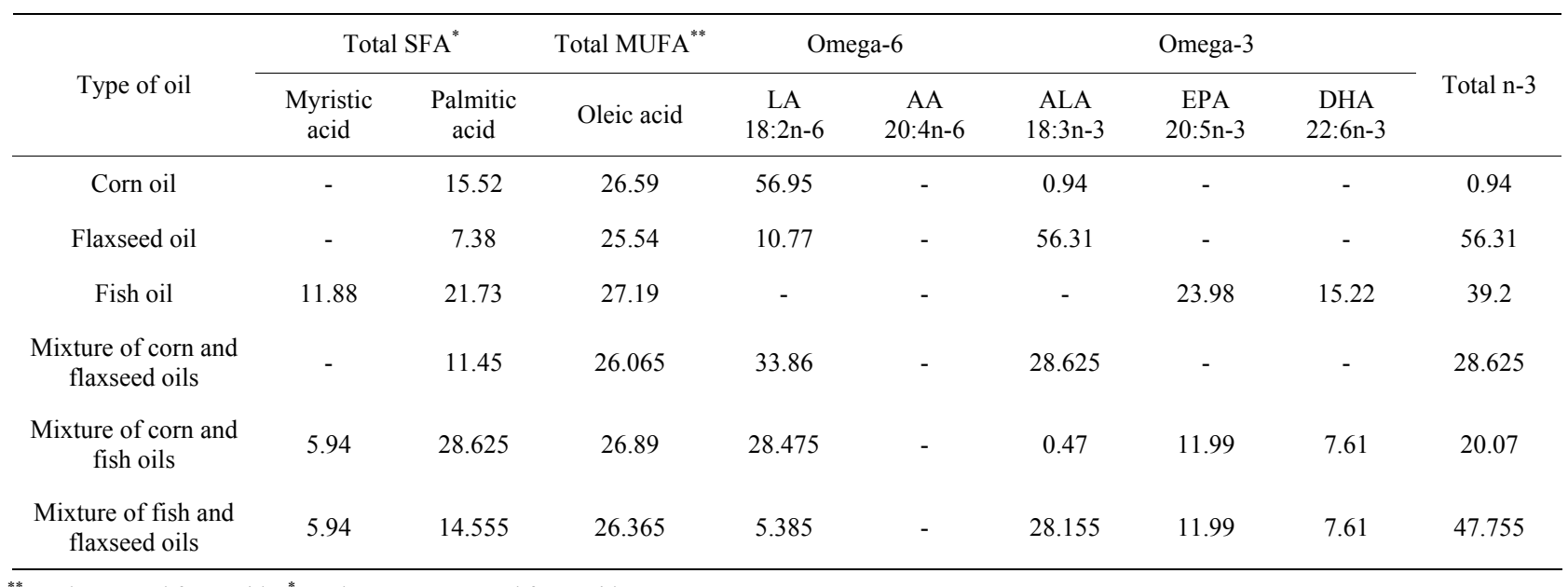

** Total saturated fatty acids; ${ }^{*}$ Total monounsaturated fatty acids. 
Table 2. Mean value \pm SD initial body weight, body weight gain, food intake and feed efficiency of experimental animal.

\begin{tabular}{|c|c|c|c|c|c|}
\hline Groups & $\begin{array}{l}\text { Initial body weight } \\
\text { Means } \pm \text { SD }\end{array}$ & $\begin{array}{c}\text { Final body weight } \\
\text { Means } \pm \text { SD }\end{array}$ & $\begin{array}{l}\text { Body weight gain } \\
\text { Means } \pm \text { SD }\end{array}$ & $\begin{array}{l}\text { Food intake daily } \\
\text { ]Means } \pm \text { SD }\end{array}$ & $\begin{array}{l}\text { Feed efficiency ratio } \\
\text { (FER) Means } \pm \text { SD }\end{array}$ \\
\hline 1) Control & $115 \pm 5.48^{\mathrm{a}}$ & $160.33 \pm 8.68^{\mathrm{a}}$ & $45.33 \pm 6.74^{\mathrm{a}}$ & $9.97 \pm 0.077^{\mathrm{a}}$ & $4.54 \pm 0.60^{\mathrm{a}}$ \\
\hline 2) Diabetic & $115 \pm 5.48^{\mathrm{a}}$ & $125.67 \pm 5.12^{\mathrm{c}}$ & $10.67 \pm 0.52^{\mathrm{b}}$ & $10.05 \pm 0.52^{\mathrm{a}}$ & $1.06 \pm 0.04^{\mathrm{b}}$ \\
\hline 3) Diabetic fish oil & $115 \pm 5.48^{\mathrm{a}}$ & $149.79 \pm 24.7^{\mathrm{ab}}$ & $34.67 \pm 80.02^{\mathrm{a}}$ & $8.0 \pm 1.13^{\mathrm{b}}$ & $4.65 \pm 2.9^{\mathrm{a}}$ \\
\hline 4) Diabetic + flaxseed oil & $115 \pm 5.48^{\mathrm{a}}$ & $155 \pm 10.48^{\mathrm{a}}$ & $40.0 \pm 8.94^{\mathrm{a}}$ & $10.16 \pm 0.52^{\mathrm{a}}$ & $3.95 \pm 0.94^{\mathrm{a}}$ \\
\hline 5) Diabetic + corn oil $+4 \%$ fish oil & $113.33 \pm 2.58^{\mathrm{a}}$ & $152.14 \pm 9.34^{\mathrm{ab}}$ & $45.33 \pm 6.74^{\mathrm{a}}$ & $8.13 \pm 0.43^{b}$ & $5.74 \pm 0.92^{\mathrm{a}}$ \\
\hline 6) Diabetic + corn oil + flaxseed & $113.33 \pm 2.58^{\mathrm{a}}$ & $150.17 \pm 17.33^{\mathrm{ab}}$ & $37.83 \pm 15.44^{\mathrm{a}}$ & $10.05 \pm 0.40^{\mathrm{a}}$ & $4.79 \pm 2.24^{\mathrm{a}}$ \\
\hline 7) Diabetic + fish oil + flaxseed oil & $113.33 \pm 2.58^{\mathrm{a}}$ & $149.33 \pm 12.8^{\mathrm{ab}}$ & $36.67 \pm 6.74^{\mathrm{a}}$ & $8.09 \pm 0.65^{\mathrm{b}}$ & $3.66 \pm 1.22^{\mathrm{a}}$ \\
\hline
\end{tabular}

Data in a columns with different superscript letters are statistically different $(P \leq 0.05)$

The present study are in a contrary with Sandgruber and Buetter, [45] who reported that the odor profiles of the fish oil were described with attributes fatty, fish like, geranium leaf like, grassy-green, malty, metallic, oily, rancid, rancid-oil like.

There is significant decrease $(P \leq 0.05 \%)$ in body weight gain in diabetic group compared to control group. Meanwhile there are no significant different in body weight gain and food efficiency ratio between different sources of omega-3.

Data in Table 3, illustrated that a significant increase $P \leq 0.05$ in plasma glucose, total cholesterol (TC), total triacylglycerol (TG), low density lipoprotein (LDL) and very low density lipoprotein (VLDL) $(238.33 \pm 4.50,128$ $\pm 8.94,209.33 \pm 30.15,52.0 \pm 5.58$ and $41.87 \pm 6.30$ $\mathrm{mg} / \mathrm{dl}$ respectively of diabetic group compared to control group $152.33 \pm 32.62,84.33 \pm 11.32,153.67 \pm 20.59$; $24.30 \pm 1.55$ and $30.73 \pm 4.11 \mathrm{mg} / \mathrm{dl}$ respectively. Similar results obtained by Yador et al., [46] and Petersen et al., [37] who reported that the administration of fructose (66\% from diet) lead to hyperglycridaemia. After 8 weeks of administration of fish oil, flaxseed oil, corn oil + fish oil, corn oil + flaxseeds oil and flaxseed oil + fish oil reduce level of glucose by $49.09 \%, 44.0 \%, 43.4 \%, 43.6 \%$ and $44.9 \%$ respectively. From these results it could be noticed that consume mainly monounsaturated fatty acid (corn oil) and short chain polyunsaturated fatty acid (flaxseed oil) and long chain polyunsaturated (fish oil) was beneficial for diabetic disease. The different oil and EPA, DHA in fish oil decrease glucose. Our results approved by Shariati et al., [47] who reported that fish oil diet and corn oil diet had an inhibitory effect on increase plasma glucose in diabetic rat by $46.8 \%$ and $40.7 \%$. Also, Djousse et al., [48] found that a higher consumption of ALA was associated with higher plasma insulin and improve glucose use and efficiency.

The present study, exhibited increase in HDL of different source of omega-3. The vast majority of studies conducted of treated with n-3 fatty acids have demon- strated $5 \%-10 \%$ increases in HDL cholesterol levels [49]. The mechanisms for this effect are not known. Should further studies confirm this finding, the increase in HDL during treatment with $\mathrm{n}-3$ fatty acids might be another antiatherogenic mechanism of these compound. The mechanisms for the effect of omega-3 fatty acid in increase HDL are not known.

Meanwhile there are decreases in total cholesterol; rate of decrease was $39.06 \%, 25 \%, 33.98 \%$ and $33.07 \%$ and $11.46 \%$ respectively of fish oil, flaxseed oil, corn oil + fish oil, corn oil + flaxseed oil and fish oil + flaxseed oil when compared to the diabetic group. Cholesterol lowering effect of flaxseed oil was lower than fish oil. In comparison of cholesterol lowering effect between fish oil (containing EPA, DHA: 39.2\%) and flaxseed oil (containing ALA: 56.31\%) a significant lower of total cholesterol was observed in fish oil group (39.06\%) but flaxseed oil was (25\%). These explained by the fact dietary flaxseed has a benefit on serum cholesterol clearance like fish oil, which may be due to increase omega-3 long chain polyunsaturated fatty acid in rats by a conversion of ALA in flaxseed oil to EPA and DHA [50].

The results in Table 3 also showed that decrease in serum triacylglycerol, LDL and VLDL of all treatments. The triglyceride-lowering effect of omega-3 fatty acids has been mainly ascribed to reduce hepatic synthetic of VLDL. Omega-3 fatty acid suppressed hepatic lipogenesis and reduced circulating TG level [51].

This results approved by Caterina et al., [52] reported that $\mathrm{n}-3$ fatty acids reduced plasma TG. N-3 fatty acid suppressed hepatic lipogemesis and reduced circulating triglyceride levels. The main effect of dietary n-3 fatty acids on plasma lipids and lipoproteins in general is reduction in plasma triglycerides by $20 \%-50 \%$ in healthy subjects and even more in subjects with hypertriglyceridemia, including diabetic patients. Morise et al., [53] observed that a higher ALA intake decrease cholesterol content in liver, however, increase in the feces. The reduced hepatic cholesterol content was accounted for 
higher cholesterol secretion into bile thus leading to a depletion of into intrahepatic pool of cholesterol [54].

Data in Table 4 illustrated that kidney function of diabetic rats fed on different sources of omega-3. It is noticed that increase in urea $(53.50 \pm 7.12 \mathrm{mg} / \mathrm{dl})$ and creatinine $(1.13 \pm 0.05 \mathrm{mg} / \mathrm{dl})$ in diabetic group compared to control group $(33.67 \pm 9.17 \mathrm{mg} / \mathrm{dl}$ and $0.77 \pm$ $0.05 \mathrm{mg} / \mathrm{dl})$. These result are agreement with Niewoehner et al., [22] reported urea were elevated in diabetic subjects. Treatment with fish oil, flaxseed, corn oil + fish oil, corn oil + flaxseed oil and fish oil + flaxseed oil decrease urea and creatinine in diabetic rats. The reduction in urea and creatinine of fish oil was more than other treatments. These result me be due to the containing fish oil on polyunsaturated EPA and DHA.

Data of glutathione reduced in Table 4 show decrease in of glutathione in diabetic rats $(1.39 \pm 0.03 \mathrm{mg} / \mathrm{dl})$ compared to control group $(2.88 \pm 0.05 \mathrm{mg} / \mathrm{dl})$. Treated with different source of omega-3 was increased of glutathione level. Fish oil revealed highest increased in glutathione levels compared to other omega-3 and no significant difference $(P \leq 0.05 \%)$ between other sources of omega-3. These results may be due contained fish oil DHA and EPA with high concentration. Similar results were obtained by with Garrel et al., [55] who reported that feeding the adequate ALA diet or enriched EPA and DHA diet increased enzyme antioxidant.

Serum zinc level was significant lower in diabetic rats $166.3 \pm 3.14 \mu \mathrm{g} / \mathrm{dl}$ as compared to control group $(362.3 \pm$ 6.71). These results approved by [56,57] reported zinc deficiency occurs in subject and animals diabetic compared to control group. While treated with different sources of omega-3 caused improved in zinc levels of diabetic rats. Fish oil was heights effect in improved zinc levels compared to the other sources of omega-3.

Data of insulin levels are shown in Table 4. Plasma insulin levels in diabetic rate were markedly decrease compared to control group. These results approved by Mahmud et al., [57] reported that insulin levels were decrease in diabetic rat. All of oils (omega-3) increased the insulin compared to the diabetic group. Meanwhile, fish oil feeding show the highest increased of insulin levels $(105.37 \pm 2.44)$ in the rats compared to the diabetic group. The reason for this is not clear, however, it

Table 3. Effect of omega-3 fatty acid on glucose, TC, TG, LDL and VLDL in diabetic rats.

\begin{tabular}{|c|c|c|c|c|c|c|}
\hline Group & $\begin{array}{l}\text { Serum glucose } \\
(\mathrm{mg} / \mathrm{dl})\end{array}$ & $\begin{array}{l}\text { Total cholesterol } \\
(\mathrm{mg} / \mathrm{dl})\end{array}$ & $\begin{array}{l}\text { Triacylglycerid } \\
\text { (mg/dl) }\end{array}$ & $\begin{array}{l}\mathrm{HDL} \\
(\mathrm{mg} / \mathrm{dl})\end{array}$ & $\begin{array}{l}\mathrm{LDL} \\
(\mathrm{mg} / \mathrm{dl})\end{array}$ & $\begin{array}{l}\text { VLDL } \\
(\mathrm{mg} / \mathrm{dl})\end{array}$ \\
\hline 1) Control & $152.33 \pm 32.62^{\mathrm{b}}$ & $84.33 \pm 11.32^{\mathrm{b}}$ & $153.67 \pm 20.59^{\mathrm{b}}$ & $36.67 \pm 4.50^{\mathrm{b}}$ & $24.30 \pm 1.55^{\mathrm{e}}$ & $30.73 \pm 4.11^{\prime}$ \\
\hline 2) Diabetic & $238.33 \pm 4.50^{\mathrm{a}}$ & $128.0 \pm 8.94^{\mathrm{a}}$ & $209.33 \pm 30.15^{\mathrm{a}}$ & $28.0 \pm 6.26^{\mathrm{c}}$ & $52.0 \pm 5.58^{\mathrm{a}}$ & $41.87 \pm 6.30^{\circ}$ \\
\hline 3) Diabetic $+8 \%$ fish oil & $105.0 \pm 11.62^{\mathrm{c}}$ & $78.0 \pm 4.73^{\mathrm{c}}$ & $103.33 \pm 10.67^{\mathrm{c}}$ & $44.67 \pm 3.39^{\mathrm{a}}$ & $38.0 \pm 3.09^{\mathrm{b}}$ & $20.67 \pm 2.13$ \\
\hline 4) Diabetic $+8 \%$ flaxseed oil & $117.0 \pm 13.42^{\mathrm{c}}$ & $96.0 \pm 22.41^{\mathrm{b}}$ & $103.0 \pm 6.75^{\mathrm{c}}$ & $41.0 \pm 2.37^{\mathrm{ab}}$ & $36.0 \pm 4.43^{b c}$ & $20.60 \pm 1.35$ \\
\hline 5) Diabetic $+4 \%$ corn oil $+4 \%$ fish oil & $103.33 \pm 7.22^{\mathrm{c}}$ & $84.50 \pm 8.91^{\mathrm{b}}$ & $129.67 \pm 26.56^{\mathrm{b}}$ & $41.50 \pm 4.59^{\mathrm{ab}}$ & $30.0 \pm 2.28^{\mathrm{d}}$ & $25.93 \pm 5.25$ \\
\hline $\begin{array}{l}\text { 6) Diabetic }+4 \% \text { corn oil }+4 \% \\
\text { flaxseed }\end{array}$ & $104.0 \pm 2.37^{c}$ & $85.67 \pm 16.62^{\mathrm{bc}}$ & $138.33 \pm 7.17^{\mathrm{b}}$ & $36.67 \pm 1.86^{\mathrm{b}}$ & $32.0 \pm 6.32^{\mathrm{cd}}$ & $27.67 \pm 1.43^{\prime}$ \\
\hline $\begin{array}{l}\text { 7) Diabetic }+4 \% \text { fish oil }+4 \% \\
\text { flaxseed oil }\end{array}$ & $107.67 \pm 10.46^{\mathrm{c}}$ & $113.33 \pm 12.24^{\mathrm{a}}$ & $147.0 \pm 26.87^{b}$ & $38.0 \pm 3.03^{\mathrm{b}}$ & $39.33 \pm 3.61^{\mathrm{b}}$ & $29.40 \pm 5.37$ \\
\hline
\end{tabular}

Data in a column with different superscript letters are statistically different $(P \leq 0.05)$.

Table 4. Effect of omega-3 fatty acid on kidney function, zinc and insulin in diabetic rats.

\begin{tabular}{lccccc}
\hline \multicolumn{1}{c}{ Groups } & Urea $(\mathrm{mg} / \mathrm{dl})$ & Creatinine $(\mathrm{mg} / \mathrm{dl})$ & Glutathione $(\mathrm{mg} / \mathrm{dl})$ & Zinc $(\mu \mathrm{g} / \mathrm{dl})$ & Insulin $(\mathrm{UI} / \mathrm{ml})$ \\
\hline 1) Control & $33.67 \pm 9.17^{\mathrm{d}}$ & $0.77 \pm 0.05^{\mathrm{de}}$ & $2.88 \pm 0.05^{\mathrm{ab}}$ & $362.3 \pm 6.71^{\mathrm{a}}$ & $108.68 \pm 1.92^{\mathrm{a}}$ \\
2) Diabetic & $53.50 \pm 7.12^{\mathrm{a}}$ & $1.13 \pm 0.05^{\mathrm{a}}$ & $1.39 \pm 0.03^{\mathrm{b}}$ & $166.3 \pm 3.14^{\mathrm{f}}$ & $61.27 \pm 1.44^{\mathrm{e}}$ \\
3) Diabetic + fish oil & $37.33 \pm 4.93^{\mathrm{cd}}$ & $0.73 \pm 0.05^{\mathrm{e}}$ & $6.46 \pm 9.4^{\mathrm{a}}$ & $299.33 \pm 5.82^{\mathrm{b}}$ & $105.37 \pm 2.44^{\mathrm{b}}$ \\
4) Diabetic + flaxseed oil & $40.33 \pm 1.37^{\mathrm{bcd}}$ & $0.90 \pm 0.09^{\mathrm{bc}}$ & $2.53 \pm 0.07^{\mathrm{ab}}$ & $247.67 \pm 8.31^{\mathrm{c}}$ & $102.05 \pm 2.30^{\mathrm{dc}}$ \\
5) Diabetic + corn oil + fish oil & $42.67 \pm 2.58^{\mathrm{bc}}$ & $0.83 \pm 0.05^{\mathrm{d}}$ & $2.47 \pm 0.05^{\mathrm{ab}}$ & $242.67 \pm 2.87^{\mathrm{c}}$ & $103.67 \pm 2.87^{\mathrm{bc}}$ \\
6) Diabetic + corn oil + flaxseed oil & $45.50 \pm 3.27^{\mathrm{b}}$ & $0.82 \pm 0.10^{\mathrm{d}}$ & $2.29 \pm 0.06^{\mathrm{ab}}$ & $210.67 \pm 2.73^{\mathrm{e}}$ & $103.90 \pm 1.46^{\mathrm{bc}}$ \\
7) Diabetic + fish oil + Flaxseed oil & $42.83 \pm 6.82^{\mathrm{bc}}$ & $0.97 \pm 0.05^{\mathrm{b}}$ & $2.50 \pm 0.04^{\mathrm{d}}$ & $229.33 \pm 3.14^{\mathrm{d}}$ & $100.63 \pm 2.76^{\mathrm{d}}$ \\
\hline
\end{tabular}

Data in a column with different superscript letters are statistically different $(P \leq 0.05)$. 
may be related to the upergulation of insulin synthesis (by $\beta$ cells) and its subsequent transport to the extracellulor milieu. This speculation is based on the fact fish oil component, particularly EPA and DHA significant increase plasma membrane fluidity [58]. Increase insulin levels is due to the stimulatory effects of omega-3, thereby potentiating the existing $\beta$ cells of the islets langerhan's in diabetic rats [59]. Mori et al., [60] reported that Both EPA and DHA significantly increase fasting insulin by $18 \%(P \leq 0.035)$ and $27 \%(P \leq 0.001)$ respectively. Some studies suggested that some of oils may improve useful against insulin resistance and type 2 diabetes mellitus [61].

\section{Histopatholagical Assessment of Pancreas}

The structure of the pancreas of the normal control and diabetic rats are shown in Figures $\mathbf{1}$ and 2. Pancreas of normal control rats showed normal islets, whereas that of diabetic animals showed atrophy of islets longerhen's hyperplasia of B cells of islets of longerhen's. However, pancreas of rats from group 3 to 7 revealed no histopathological changes (Figures 3-7). This results agreement with Riccillo et al., [62] and Verma et al., [63] reported the type-2 diabetic induce markedly abnormal change in rat islets. Omega- 3 protected the pancreatic $\beta$-cells may be by decrease oxidative stress and preserving pancreatic

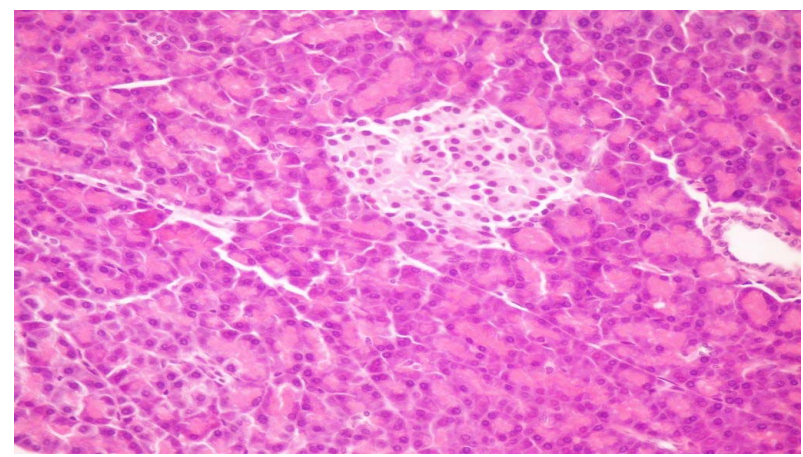

Figure 1. Pancreas of control group 1 showing no histopathological change.

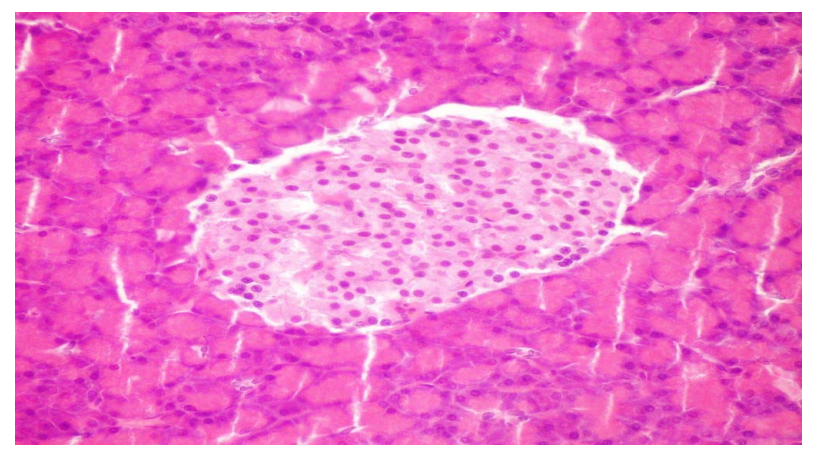

Figure 2. Pancreas of diabetic rat (group 2) showing hyperplasia of B cells of islets of hangerhan's.

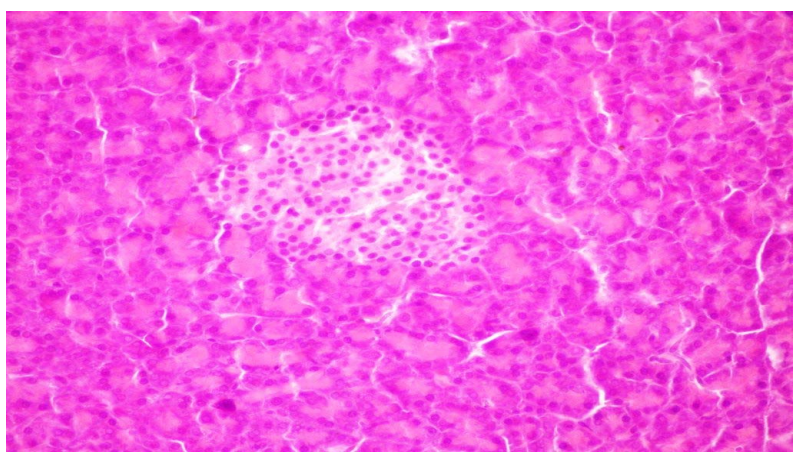

Figure 3. Pancreas of rats from group 3 fed on $8 \%$ fish oil showing no histopathological changes.

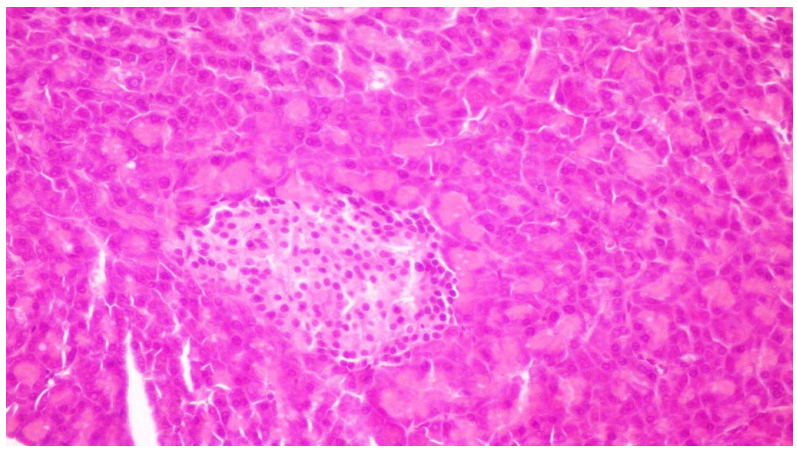

Figure 4. Pancreas of rats from group 4 fed on $8 \%$ flaxseed oil showing no histopathological changes.

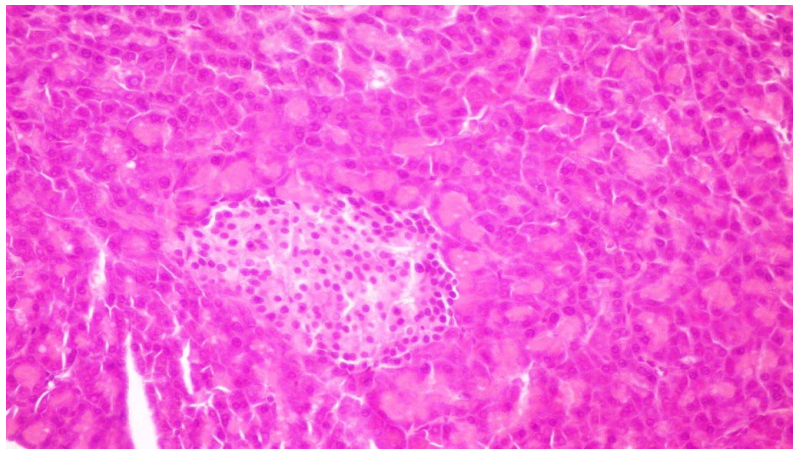

Figure 5. Pancreas of rats from group 5 fed on $4 \%$ corn oil + $4 \%$ fish oil showing no histopathological changes.

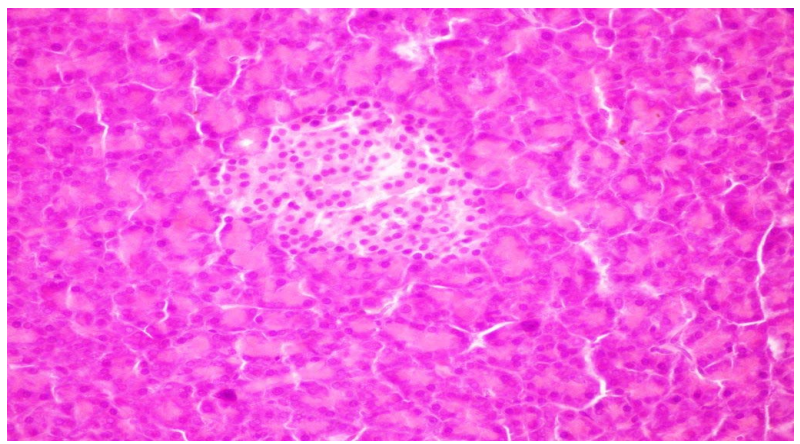

Figure 6. Pancreas of rats from group 6 fed on $4 \%$ corn oil + $4 \%$ flaxseed oil showing no histopathological changes. 


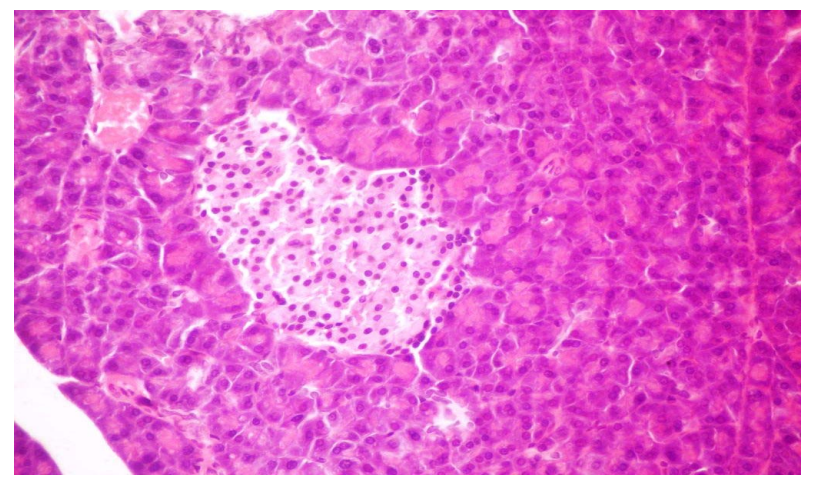

Figure 7. Pancreas of rats from group 7 fed on $4 \%$ fish oil + $4 \%$ flaxseed oil showing no histopathological changes (X400).

$\beta$-cells integrity [52].

\section{Conclusion}

In view of these data, it is possible to the omega-3 fatty acid especially Long chain polyunsaturated fatty acid (EPA, DHA) in fish oil have antidiabetic effect. Fish oil were more effective of reduction glucose, TC, TG, LDL, Creatinene and Urea more than other sources of omega-3 fatty acids in diabetic rats. Omega-3 fatty acids have potential effect to protect pancreas from up normality changes which induced in diabetic disease. The data suggested that, omega-3 fatty acid specifically long chain (EPA and DHA in fish oil) may be beneficial in diabetic disease.

\section{REFERENCES}

[1] G. G. Adams, S. Imran, S. Wang, A. Mohammad, S. Kok, D. A. Gray, G. A. Channell, G. Morris and S. Harding, "The Hypoglycemic Effect of Pumpkins as Anti-Diabetic and Functional Medicines," Food Research International, Vol. 44, No. 4, 2011, pp. S862-S867. doi:10.1016/j.foodres.2011.03.016

[2] N. Zangiabad, M. N. Ahrari and M. N. Nakhaee, "The Effect of Omega-3 Fatty Acid on Nerve Conduction Velocity (NCV) and F-Wave Latency in Patients with Diabetic Polyneropathy," American Journal Pharmacology and Toxicology, Vol. 2. No. 1, 2007, pp. 1-3. doi:10.3844/ajptsp.2007.1.3

[3] G. D. Susan, "Nutrition Essentials for Nursing Practice," Fifth Edition, Lippin CoH, Williams \& Wilkins, Philadelphia, 2006.

[4] G. Steiner, "Treating Lipid Abnormalities in Patients with Type-2 Diabetes Mellitus," American Journal of Cardiology, Vol. 88, 2001, pp. 37-40. doi:10.1016/S0002-9149(01)02151-8

[5] B. N. Howard, "Lipoprotein Metabolism in Diabetes Mellitus," Journal of Lipid Research, Vol. 28, 1987, pp. 613628.

[6] M. F. Jorgensen, P. Bjergaard and K. Barchjohnsen,
"Diabetes and Impaired Glucose Tolerance among the I Unit Population of Greenland," Diabetes Care, Vol. 25, No. 10, 2002, pp. 1766-1771. doi:10.2337/diacare.25.10.1766

[7] N. R. Burrows, L. S. Geiss, M. M. Engelgaum and K. J. Acton, "Prevalence of Diabetes among Native Americans and Alaska Natives, 1990-1997: An Increasing Burden," Diabetes Care, Vol. 23, No. 12, 2000, pp. 1770-1786. doi:10.2337/diacare.23.12.1786

[8] T. Simonsen, F. A. Vartun, V. Lyngmo and A. Nordoy, "A Coronary Heart Disease, Serum Lipid, Platelets and Dietary Fish in Two Communities in Northern Norway," Acta Medica Scandinavica, Vol. 222, No. 3, 1987, pp. 237-243. doi:10.1111/j.0954-6820.1987.tb10665.x

[9] C. D. Schraer, A. P. Lanier, E. J. Boyko, D. Gohdes and N. J. Murphy, "Prevalence of Diabetes Mellitus in Alaskan Eskimos, Indians and Aleuts," Diabetes Care, Vol. 11, No. 9, 1988, pp. 693-700. doi:10.2337/diacare.11.9.693

[10] N. Kromann and A. Green, "Epidemiological Studies in the Upernavik District, Greenland: Incidence of Some Chronic Diseases 1950-1974," Acta Medica Scandinavica, Vol. 208, No. 1-6, 1980, pp. 401-406. doi:10.1111/j.0954-6820.1980.tb01221.x

[11] S. O. Ebbesson, P. M. Risica, L. O. Ebbesson and J. M. Krnnish, "Eskimo Have CHD despite High Consumption of Omega-3 Fatty Acid: The Alaska Siberia Project," International Journal of Circumpolar Health, Vol. 64, No. 4, 2005, pp. 387-395.

[12] N. A. S Arafa and G. E. E. Amin, "The Epidemiology of Diabetes Mellitus in Egypt: Results of a National Survey," The Egyptian Journal of Community Medicine, Vol. 28, No. 3, 2010, pp. 29-43.

[13] D. Rodriguez-Leyva, C. M. C. Bassett, R. McCullough and G. N. Pierce, "The Cardiovascular Effects of Flaxseed and Its Omega-3 Fatty Acid, Alpha-Linolenic Acid," Canadian Journal of Cardiology, Vol. 26, No. 9, 2010, pp. 489-496. doi:10.1016/S0828-282X(10)70455-4

[14] J. A. Austria, M. N. Ichard and M. N. Chahine, "Bioavailability of Alpha Linolenic Acid in Subject after Ingestion of Three Different Forms of Flaxseed," Journal American Call Nutrition, Vol. 27, 2008, pp. 214-221.

[15] O. P. Ward and A. Singh, "Omeg-3/6 Fatty Acids Alterative Sources of Production," Process Biochemistry, Vol. 40 , No. 12,2005 , pp. 3627-3652. doi:10.1016/i.procbio.2005.02.020

[16] T. Linn, M. Noke, M. Wochrie, H. U. Kloer, H. P. Hammes, D. Litzlbauer, R. G. Bretzal and K. Federlin, "Fish Oil-Enriched Diet and Reduction of Low Dose Streptozocin Induced Hyperglycemia. Inhibition of Macrophage Activation," Diabetes, Vol. 38, 1989, pp. 1402-1411. doi:10.2337/diabetes.38.11.1402

[17] J. Bresson, A. Flywn, M. Heinonen, K. Hulsh, H. Korhonen, P. Lagiou and M. Louk, "Labeling Reference Intake Value for n-3 and n-6 Polyunsaturated Fatty Acids," European Food Safety Authority, Vol. 1, 2000, pp. 1-11.

[18] L. Djousse, J. S. Pankow and J. H. Eckfeldt, "Relation between Dietary Linolenic Acid and Coronary Artery Disease in the National Heart, Lung and Blood Institute 
Family Heart Study," American Journal of Clinical Nutrition, Vol. 74, No. 5, 2001, pp. 612-619.

[19] J. Ruzickowa, M. Rossmeisl and T. Prazak, "Omega-3 PUFA of Marine Origin Limit Diet-Induced Obesity in Mice by Reducing Cellularity of Adipose Tissue," Journal of Lipid, Vol. 39, No. 12, 2004, pp. 1177-1185. doi:10.1007/s11745-004-1345-9

[20] C. Delarue, C. Lefoll, C. Corporcnu and D. Luce, "N-3 Long Chain Polyunsaturated Fatty Acid. A Nutritional Food to Prevent Insulin Resistance Associated to Type-2 Diabetes and Obesity," Reproduction Nutrition Development, Vol. 44, 2000, pp. 289-299. doi:10.1051/rnd:2004033

[21] J. P. Schuchardt, H. Michael, M. Statuss-Grabo and A. Hahn, "Significance of Long-Chain Polyunsaturated Fatty Acids (PUFA) for the Development and Behavior of Children," European Journal of Pediatric, Vol. 169, No. 2, 2010, pp. 149-164. doi:10.1007/s00431-009-1035-8

[22] C. B. Niewoehner, J. I. Allen, M. Boosalis, A. S. Levine and J. F. Moriey, "Role of Zinc Supplementation in Type-1 Diabetes Mellitus," American Journal of Medicine, Vol. 81, No. 1, 1986, pp. 63-68. doi:10.1016/0002-9343(86)90183-X

[23] E. G. Bligh and W. J. Dyer, "A Rapid Method of Total Lipid Extraction and Purification," Canada Journal of Biochemical Physiology, Vol. 37, No. 8, 1959, pp. 911917. doi:10.1139/059-099

[24] R. A. Gibson and G. M. Kneebone, "Fatty Acid Composition and Mature Milk," American Journal of Clinical Nutrition, Vol. 34, No. 2, 1981, pp. 252-257.

[25] AOAC, "Official Methods of Analysis," 17th Edition, AOAC International Sut, Gaithersburg, 2000.

[26] S. P. Yador, A. Vats, A. Ammin and J. K. Grover, "Brassica Juncea (Rai) Significantly Prevented the Development of Insulin Resistance in Rats Fed Fructose Enriched Diet," Journal of Ethropharmacology, Vol. 93, No. 1, 2004, pp. 113-116. doi:10.1016/j.jep.2004.03.034

[27] P. Trinder, "Determination of Glucose in Blood," Annals of Clinical Chemistry, Vol. 6, 1969, p. 24.

[28] N. Richmond, "Preparation and Properties of a Cholesterol Oxidase from Nacardia sp. Enzymatic Assay of Total Cholesterol in Serum," Clinical Chemistry, Vol. 19, No. 12, 1973, pp. 1350-1356.

[29] M. Burstein, H. R. Scholinck and R. Haarfin, "Rapid Method for the Isolation of Lipoprotein from Human Serum by Precipitation with Polyanions," Lipid Research, Vol. 11, No. 6, 1970, pp. 583-595.

[30] H. Wieland and D. Seidel, "A Simple Specific Method for Precipitation of Low Density Lipoprotein," Journal of Lipid Research, Vol. 24, 1983, pp. 904-909.

[31] N. Jacobs and P. J. Vandermark, "Determination of Serum Triacylglycerol," Archives of Biochemistry Biophysics, Vol. 88, No. 2, 1960, pp. 250-261. doi:10.1016/0003-9861(60)90230-7

[32] C. J. Patton and S. R. Crouch, "Spectrophotometric and Kinetics Investigation of the Berthelot Reaction for the Determination of Ammonia," Analytical Chemistry, Vol. 49, No. 3, 1977, pp. 464-469. doi:10.1021/ac50011a034

[33] K. Larson, "Creatinine Assay by a Reaction Principle," Clinical Chemical Acta, Vol. 41, 1972, pp. 209-217. doi:10.1016/0009-8981(72)90513-X

[34] E. Beutler, O. Duron and M. B. Kelly, "Determination of Reduced Glutathione," Journal of Laboratory and Clinical Medicine, Vol. 61, 1963, pp. 882-891.

[35] R. J. Hayakawa, "Determination of Serum Zinc," Journal of Toxicology Environment Health, Vol. 8, 1961, pp. 1418.

[36] G. W. Snedecore and W. G. Cochran, "Statistical Methods," 6th Edition, Lowa State University Press, Oxford, 1967.

[37] M. Petersen, H. Pedersen, A. M. Pedersen, T. Jansen and P. Marckmann, "Effect of Fish Oil versus from Corn Oil Supplementation LDL and HDL Subclasses in Type-2 Diabetic Patients," Diabetes Care, Vol. 25, No. 10, 2002, pp. 1704-1708. doi:10.2337/diacare.25.10.1704

[38] R. J. Henderson and D. R. Tochor, "Fatty Acid Metabolism in Fresh Water Fish with Particular Reference to Polyunsaturated Fatty Acids," Arch Animal Nutrition, Vol. 49, 1996, pp. 5-22.

[39] A. Hugo, "Variability in Oil Content and Fatty Acid Composition of Ethiopian Introduction Cultivars of Linseed," Journal of the Science of Food and Agriculture, Vol. 84, No. 7, 2004 , pp. 601-607.

[40] S. S. A. Soltan, "Determination of Fat Content and Fatty Acid Constituents in Different Food Items in Egypt and Australia," Annals of Agriculture, Science, Moshtohor, Vol. 46, No. 2, 2008, pp. 69-81.

[41] N. M. El-Shimi, H. Zaghlol, S. A. Soliman and S. G. Qorraa, "Effect of Chufa Nut and Flaxseed on Lipid Prophile of Rats Feed on Hypercholesterolemic Diet," Egyptian Journal of Nutrition, Vol. 26, No. 2, 2011, pp. 101123.

[42] M. J. James and L. G. Cleland, "Fats and Oils," The Facts Lea Food Ltd., Macquarie Park, 2000.

[43] M. Makrides, M. Neumann, K. Simmer, J. Peter and R. Gibson, "Are Long Chain Polyunsaturated Fatty Acids Essential Nutrients in Infancy?" The Lancet, Vol. 345, No. 8965, 1995, pp. 1463-1468.

[44] E. Campioli, C. Rustichelli and R. Avallone, "N-3 Dietary Supplementation and Lipid Metabolism: Difference between Vegetable and Fish-Derived Oils," Journal of Functional Foods, Vol. 4, No. 1, 2012, pp. 207-212. doi:10.1016/j.jff.2011.10.006

[45] S. Sandgruber and A. Buetter, "Comparative Human-Sensory Evaluation and Quantitative Comparison of OdourActive Oxidation Markers of Encapsulated Fish Oil Products Used for Supplementation during Pregnancy and the Breastfeeding Period," Food Chemistry, Vol. 133, No. 2, 2012, pp. 458-466. doi:10.1016/j.foodchem.2012.01.072

[46] S. P. Yador, V. Vats, A. Ammin and J. K. Grover, "Brassica Juncea (Rai) Fructose Enriched Diet," Journal of Ethropharmacology, Vol. 93, No. 1, 2004, pp. 113-116.

[47] M. Shariati, M. T. Mohammad and R. J. Hamid, "Effect of Dietary Fish Oil and Corn Oil in Blood Biochemical 
Factors in Diabetic Rats," Clinical Biochemistry, Vol. 44, No. 13, 2011, pp. 133-140.

doi:10.1016/j.clinbiochem.2011.08.318

[48] L. Djousse, S. C. Hunt, W. Tang, J. H. Eckfelatt, M. A. Province and R. C. Ellison, "Dietary Linolienic Acid and Fasting Glucose and Insulin: The National Heart, Lung and Blood Institute Family Heart Study," Obesity, Vol. 14, 2006, pp. 205-500. doi:10.1038/oby.2006.38

[49] W. S. Harris, "Fish Oils and Plasma Lipid and Lipoprotein Metabolism in Humans: A Critical Review," Journal of Lipid Research, Vol. 30, No. 6, 1989, pp. 123-131.

[50] B. Tzang, S. Yang, S. Fu, H. Yang, H. Sun and Y. Chen, "Effect of Dietary Flaxseed Oil on Cholesterol Metabolism of Hamsters," Food Chemistry, Vol. 114, No. 4, 2009, pp. 1450-1455. doi:10.1016/j.foodchem.2008.11.030

[51] H. H. Strolien, A. D. Kriketos, G. D. Calvert, L. A. Baur and A. B. Jenkins, "Fatty Acids, Triglycerides and Syndromes of Insulin Resistance. Prostaglandins and Plasma Lipid and Lipoprotein Metabolism in Human: A Critical Review," Diabetes Care, Vol. 30, No. 4, 2007, pp. 10121024.

[52] R. D. Caterina, R. MaDonna, A. B. Lotto and E. B. Schmidt, "N-3 Fatty Acids in the Treatment of Diabetic Patients," Diabetes Care, Vol. 30, No. 4, 2007, pp. 10121024. doi: $10.2337 / \mathrm{dc} 06-1332$

[53] A. Morise, J. Mourot, M. Riottot, P. Well, E. Fenart and D. Hermier, "Dose Effect of Alpha-Linolenic Acid on Lipid Metabolism in the Hamster," Reproduction Nutrition Development, Vol. 45, No. 4, 2005, pp. 405-418. doi:10.1051/rnd:2005037

[54] K. Vijaimohan, M. Jainu, K. E. Sabitha, S. Suberananivan, C. Anandhan and C. Shyamala, "Beneficial Effects of Alpha-Linolenic Acid Rich Flaxseed Oil on Growth Performance and Hepatic Cholesterol Metabolism in High Fat Diet Rats," Life Science, Vol. 79, No. 5, 2006, pp. 448-454. doi:10.1016/j.lfs.2006.01.025

[55] C. Garrel, J. M. Alessandri, P. Guesent and K. H. AlGubory, "Omega-3 Fatty Acids Enhance Mitochondria Superoxide Dismutase Activity in Rat Organs during Post-Natal Development," The International Journal of Biochemistry \& Cell Biology, Vol. 44, No. 1, 2011, pp. 123-131. doi:10.1016/j.biocel.2011.10.007

[56] N. Masood, G. H. Baloch, R. A. Ghori, M. A. Memon and M. S. Memon, "Serum Zinc and Magnesium in Type2 Diabetic Patients," Journal of Cell Physician Surge Pak, Vol. 19, No. 8, 2009, pp. 483-486.

[57] I. Mahmud, A. Hossain, S. Hossain, A. Hannan, L. Ali and M. Hashimoto, "Effect of Hilsa L. Lisa Fish Oil on the Atherogenic Lipid Profile and Glycaemic Status of Streptozotocin Treated Type-1 Diabetic Rats," Clinical and Experimental Pharmacology and Physiology, Vol. 31, No. 1-2, 2004, pp. 76-81. doi:10.1111/j.1440-1681.2004.03953.x

[58] M. Hashimoto, M. S. Hossian, H. Yamasaki, K. Yazawa and S. Masurmura, "Effects of Eicosapantaenoic Acid and Docosahexaenoic Plasma Membrane Fluidity of Aortic Endothelial Cell," Lipids, Vol. 34, No. 12, 1999, pp. 1297-1304. doi:10.1007/s11745-999-0481-6

[59] V. R. Punithavathi, P. S. Prince, R. Kumar and J. Selvakumari, "Antihyperglycemic, Antilipid and Antioxidant Effects of Gallic Acid on Streptozotocin Induced Diabetic Wister Rats," European Journal of Pharmacology, Vol. 650 , No. 1, 2011, pp. 465-471. doi:10.1016/j.ejphar.2010.08.059

[60] T. A. Mori, V. Burke, I. B. Puddey, G. F. Watts, D. N. O'Neal, J. D. Best and L. Bellin "Purified Eicosapentaenoic and Docosahexaenoic Acids Have Different Effect on Serum Lipid and Lipoprotein, LDL Particle Size, Glucose and Insulin in Mildly Hyperlipidemic Men," American Journal of Clinical Nutrition, Vol. 71, No. 5, 2000, pp. 1085-1094.

[61] H. Ping, G. Zhang and G. Ren, "Antidiabetic Effects of Cinnamon Oil Diabetic KU-A Mice," Food and Chemical Toxicology, Vol. 48, No. 8-9, 2010, pp. 2344-2449. doi:10.1016/j.fct.2010.05.069

[62] F. L. Riccillo, M. I. Bracamonet, S. Martinez and J. R. Ronderos, "Progressive Rat Model of Type-2 Diabetic," Tissue and Cell, Vol. 44, No. 2, 2012, pp. 101-110. doi:10.1016/j.tice.2011.12.002

[63] N. Verma, G. Amresh, P. K. Sahu, N. Mishra, A. P. Singh and Ch.-V. Reo, "Antihyperglycemic Activity, Antihyperlipedemic Activity, Hematological Effects and Histopathological Analysis of Sapindu Mukorossi Gaerten Fruit in Streptoztocin Induce Diabetic Rats," Asia Pacific Journal of Tropical Medicine, Vol. 2, No. 3, 2012, pp. 785-807. 